\title{
UJI EFEKTIVITAS KONSENTRASI AIR KELAPA MUDA DAN EKSTRAK KECAMBAH JAGUNG TERHADAP PERTUMBUHAN JAMUR TIRAM (Pleurotus ostreatus)
}

\author{
Oleh: \\ Angga Adriana Imansyah*) \\ Melissa Syamsiah*) \\ Livia Putri Sumirat**)
}

\begin{abstract}
Abstrak
Jamur tiram putih (Pleurotus ostreatus) merupakan jenis jamur pangan dari kelompok Basidiomycota. Saat ini produksi jamur tiram (Pleurotus ostreatus) perlu ditingkatkan karena permintaan pasar yang meningkat. Salah satu cara untuk meningkatkan produksi jamur tiram putih yaitu dengan pemberian zat pengatur tumbuh diantaranya menggunakan ekstrak kecambah jagung dan air kelapa muda. Penelitian ini bertujuan untuk menguji efektivitas pemberian kedua ZPT alami tersebut terhadap pertumbuhan miselium, berat basah, jumlah rumpun, jumlah tudung dan tinggi buah. Penelitian ini dilaksanakan pada bulan Febuari sampai bulan April 2020. Penelitian ini menggunakan Rancangan Acak Lengkap (RAL) faktorial dengan dua faktor perlakuan. Faktor I adalah air kelapa muda (K) dengan tiga taraf yaitu K1: air kelapa muda (200ml), K2: air kelapa muda $(300 \mathrm{ml})$, K3: air kelapa muda $(400 \mathrm{ml})$. Faktor II adalah ekstrak kecambah jagung (E) yang terdiri dari tiga taraf perlakuan: E1 ekstrak kecambah jagung $(200 \mathrm{ml})$, E2 ekstrak kecambah jagung $(300 \mathrm{ml})$, E3 ekstrak kecambah jagung $(400 \mathrm{ml})$. Parameter yang diamati adalah pertumbuhan miselium, berat basah, jumlah rumpun, jumlah tudung buah dan tinggi buah. Hasil penelitian menunjukan efektivitas pemberian air kelapa muda dengan dosis $400 \mathrm{ml}$ berkode $\mathrm{K} 3$ menunjukan pengaruh yang nyata terhadap jumlah tudung buah, sedangkan pemberian ekstrak kecambah jagung dengan tiga dosis yang berbeda tidak menunjukan pengaruh yang nyata terhadap kelima parameter yang diteliti. Interaksi yang terbaik adalah kombinasi antara E3K3 (ekstrak kecambah jagung $400 \mathrm{ml}$ dan air kelapa muda $400 \mathrm{ml}$ ) terhadap pertumbuhan miselium.
\end{abstract}

Kata kunci: Air kelapa muda, Ekstrak kecambah jagung, Jamur tiram putih (Pleurotus ostratus).

\section{Abstract}

White oyster mushroom (Pleurotus ostreatus) is a type of edible mushroom from the Basidiomycota group. Nowadays the production of oyster mushroom (Pleurotus ostreatus) needs to be increased as market demand increases. One of the solutions to increase the production of white oyster mushrooms is by adding plant growth regulators such as corn sprout extract and young coconut water. This study aims at investigating the effectiveness of two natural plant growth regulators wich are young coconut water concentrate and extract corn sprouts on mycelium growth, wet weight, number of clumps, number of caps and fruit height. This research was conducted in February to April 2020. This research used factorial completely randomized design (CRD) with two treatment factors. Factor I was young coconut water (K) with three levels, namely K1: young coconut water (200ml), K2: young coconut water (300ml), K3: young coconut water $(400 \mathrm{ml})$. Factor II is extract of corn sprouts (E) wich consist of three treatment levels: E1 corn sprout extract (200ml), E2 com sprout extract $(300 \mathrm{ml})$, E3 corn sprout extract $(400 \mathrm{ml})$. The parameters observe were mycelium growth, wet weight, number of clumps, number of caps and fruit height. The result showed that the effectiveness of young coconut water at a dose of $400 \mathrm{ml}$ or $\mathrm{K} 3$ showed a significant effect on the number of fruit caps, while the use of corn sprouts extract with three different doses did not show any effect on the five parameters studied. The best

UJI EFEKTIVITAS KONSENTRASI AIR KELAPA MUDA DAN EKSTRAK KECAMBAH JAGUNG TERHADAP PERTUMBUHAN JAMUR TIRAM (Pleurotus ostreatus)
ANGGA ADRIANA IMANSYAH, MELISSA SYAMSIAH dan LIVIA PUTRI SUMIRAT 
interaction is the combination of E3K3 which consist of $400 \mathrm{ml}$ corn sprouts extract and $400 \mathrm{ml}$ young coconut water on mycelium growth.

Keywords : Young Coconut Water, Extract of Corn Sprouts, White Oyster Mushroom (Pleurotus ostreatus).

*) Dosen Fakultas Sains Terapan UNSUR.

**) Alumni Fakultas Sains Terapan UNSUR. 


\section{PENDAHULUAN}

Jamur tiram putih (Pleurotus ostreatus) merupakan jenis jamur pangan dari kelompok Basidiomycota yang dapat ditemui di alam bebas sepanjang tahun. Jamur tiram merupakan salah satu jenis jamur kayu yang tumbuh di permukaan batang pohon yang sudah lapuk atau pada batang pohon yang sudah ditebang. Nama jamur tiram diambil dari bentuk tudungnya yang melengkung, lonjong, dan membulat menyerupai kerang atau cangkang tiram dengan bagian tepi yang bergelombang.

Saat ini produksi jamur tiram (Pleurotus ostreatus) perlu ditingkatkan karena permintaan pasar yang meningkat. Salah satu cara untuk meningkatkan produksi jamur tiram putih yaitu dengan pemberian zat pengatur tumbuh. Zat pengatur tumbuh dibagi menjadi dua yaitu zat pengatur tumbuh alami dan sintetik. Zat pengatur tumbuh digolongkan menjadi 5 kelompok yaitu, Sitokinin, Giberelin, Auksin, Asam Absisat, dan Etilen. Penelitian ini menggunakan zat pengatur tumbuh alami umumnya tersedia langsung di alam dan berasal dari bahan organik, diantaranya adalah air kelapa muda dan ekstrak kecambah jagung.

Air kelapa mengandung gula, asam organik, dan asam amino serta mikro mineral yang bermanfaat sebagai sumber nutrisi untuk pertumbuhan jamur. Air kelapa juga mengandung hormon sitokinin, auksin dan giberelin yang dapat memacu pertumbuhan. Ketiga sumber zat pengatur tumbuh ini dapat menggantikan perangsang akar sintetis (Yong et.al., 2009) sedangkan ekstrak kecambah mengandung karbohidrat, protein, $\mathrm{Ca}, \mathrm{P}, \mathrm{Fe}$ dan vitamin $\mathrm{A}, \mathrm{B} 1, \mathrm{C}$ yang berbentuk senyawa terlarut yang mudah diserap tanaman (Amilah, 2006 dalam Rajiman, 2018). Maka dari itu penelitian ini bertujuan untuk menguji efektivitas pemberian kedua ZPT alami tersebut terhadap pertumbuhan miselium, berat basah, jumlah rumpun, jumlah tudung dan tinggi buah.

\section{METODE PENELITIAN}

Penelitian ini dilaksanakan pada bulan Februari sampai April tahun 2020. Penelitian dilakukan di kebun percobaan yang berlokasi di Kp. Tegal Pari, Desa Kadupandak, Kecamatan Kadupandak, Kabupaten Cianjur, Provinsi Jawa Barat.

Dalam pelaksanaan penelitian ini penulis menggunakan beberapa alat serta bahan yang diperlukan. Alat yang digunakan adalah timbangan digital, saringan, blender, alat sterilisasi, handsprayer, gelas ukur, penggaris, spuit (jarum suntik), label nama, alat tulis, dan kamera digital. Sedangkan bahan yang digunakan yaitu benih jamur tiram, baglog, air kelapa, ekstrak jagung muda, dan air.

\section{Pelaksanaan penelitian}

Penelitian ini dilaksanakan dalam beberapa tahapan kegiatan sebagai berikut:

1. Pembuatan Rumah/Kumbung Jamur Skala Kecil

Pembuatan rumah jamur biasanya dibuat dari bahan-bahan sederhana yang ada disekitar seperti bambu, dinding bilik (anyaman bambu), untuk atap bisa dari genting, dan anyaman jerami padi. Beberapa peralatan yang digunakan untuk membuat kumbung jamur diantaranya adalah gergaji, palu dan meteran. Dalam pembuatannya, pertama membuat pondasi dan kerangka terlebih dahulu dengan menggunakan bambu, setelah kerangka berdiri dengan kokoh selanjutnya adalah menutupi sisi-sisinya dengan menggunakan bilik (anyaman bambu) dan melapisinya dengan plastik terpal atau paranet. Atap dapat menggunakan genting. Rumah jamur dilengkapi dengan rak-rak untuk menyimpan baglog atau media tumbuh jamur di dalamnya, dengan jarak antar rak 60-70 $\mathrm{cm}$. Setelah rumah jamur jadi, maka dilakukan sterilisasi dengan menyemprotkan alkohol di dalam rumah jamur, kemudian tunggu 1-2 
hari dan rumah jamur siap untuk dipakai. Untuk ukuran rumah jamur dalam penelitian ini adalah $2 \mathrm{X} 2$ meter karena disesuaikan dengan jumlah baglog.

2. Penyiapan Baglog

Baglog atau media tanam untuk menumbuhkan jamur tiram didapatkan dari CV Asa Agro. Media tanam atau baglog yang digunakan adalah yang sudah siap pakai dan media tanam atau baglog yang dibutuhkan adalah sebanyak 54.

3. Penyiapan Air Kelapa Muda

Air kelapa muda yang akan digunakan dalam penelitian ini didapatkan langsung dari pohon kelapa yang berada di Kp. Tegal Pari. Desa Kadupandak. Kecmatan Kadupandak. Kabupaten Cianjur, Jawa Barat.

4. Pembuatan Ekstrak Kecambah Jagung Pembuatan ekstrak Kecambah jagung yaitu dengan cara kecambah jagung diblender sampai halus, kemudian kecambah jagung yang telah diblender disaring menggunakan saringan (Ulfa, 2014). Cairan yang turun melalui saringan adalah ekstrak dari jagung muda, ekstrak itu yang akan dipakai dalam penelitian ini.

\section{Rancangan Penelitian}

Rancangan yang digunakan pada penelitian ini adalah Rancangan Acak Lengkap (RAL) pola faktorial dengan 2 faktor, yaitu :

1. Faktor I : konsentrasi air kelapa muda (K) yaitu:

a. $\mathrm{K} 1: 200 \mathrm{ml} /$ baglog

b. $\mathrm{K} 2: 300 \mathrm{ml} /$ baglog

c. $\mathrm{K} 3: 400 \mathrm{ml} / \mathrm{baglog}$

2. Faktor II : Konsentrasi ekstrak Kecambah Jagung (E) yaitu:

a. E1 : $200 \mathrm{ml} /$ baglog

b. E2 : $300 \mathrm{ml} /$ baglog

c. E3 : $400 \mathrm{ml} /$ baglog Berdasarkan faktor perlakuan dan kombinasi perlakuan, penelitian ini menggunakan 3 ulangan dan 2 sampel baglog.

\section{Analisis Data}

Data yang didapatkan dari hasil pengamatan akan dianalisis menggunakan bantuan komputer di Software Microsoft Excel dan aplikasi SAS. Hasil pengolahan yang telah didapatkan kemudian akan dianalisis melalui ANOVA atau sidik ragam, dan dibandingkan dengan $\mathrm{F}$ tabel. Jika terdapat perbedaan maka akan dilanjutkan dengan uji beda nyata antar perlakuan menggunakan Uji Duncan Multiple Range Test (DMRT) pada alpha $5 \%$, dengan menggunakan aplikasi SAS.

\section{HASIL DAN PEMBAHASAN}

\section{Pertumbuhan Miselium}

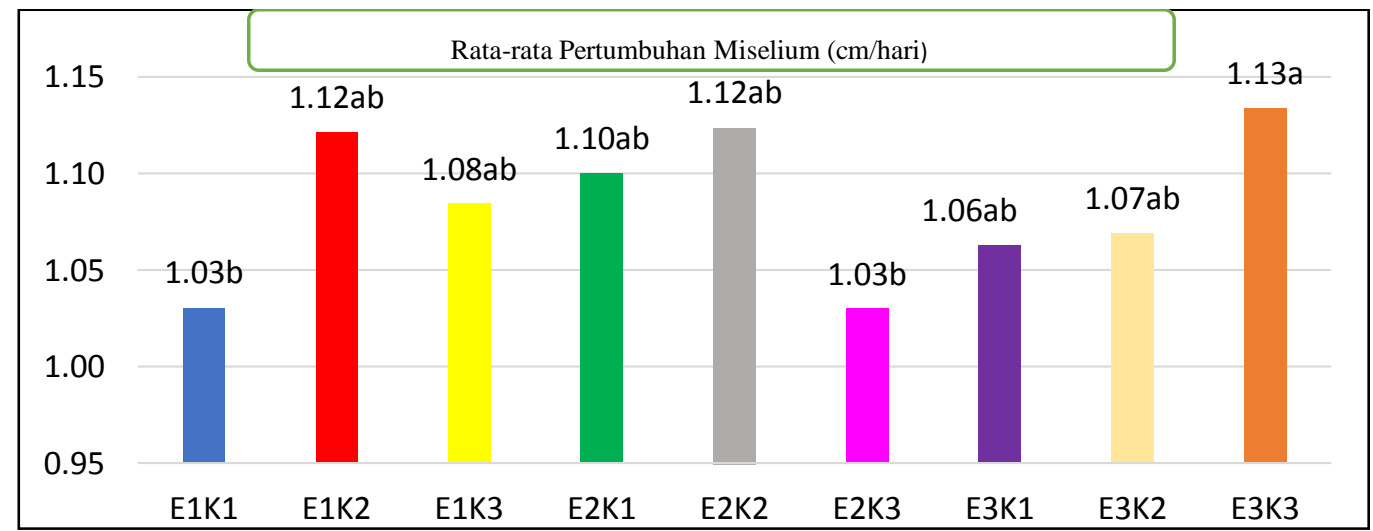

Gambar 1. Grafik rata-rata Pertumbuhan miselium.

UJI EFEKTIVITAS KONSENTRASI AIR KELAPA MUDA DAN EKSTRAK KECAMBAH JAGUNG TERHADAP PERTUMBUHAN JAMUR TIRAM (Pleurotus ostreatus)
ANGGA ADRIANA IMANSYAH, MELISSA SYAMSIAH dan LIVIA PUTRI SUMIRAT 
Grafik di atas menunjukkan bahwa perlakuan E3K3 memiliki nilai rata-rata 1.13a sehingga menjadikan perlakuan ini perlakuan paling baik dibandingkan dengan perlakuan yang diikuti notasi ab dan b. Hal ini diduga karena pertumbuhan miselium sampai memenuhi baglog dipengaruhi nutrisi yang terkandung dalam media jamur tiram. Glukosa yang terkandung dalam air kelapa muda menjadi salah satu faktor dalam pemenuhan miselium. Glukosa sendiri merupakan sumber karbon sebagai unsur makronutrien, karbon tersebut dibutuhkan oleh jamur sebagai penyusun struktur sel (Rahayu \& Setyo, 2015).

\section{Berat Basah Jamur Tiram}

Tabel 1. Rata-rata berat basah jamur tiram (Pleurotus ostreatus).

\begin{tabular}{cc}
\hline Perlakuan & Rata-Rata Berat Basah Jamur Tiram (Pleurotus ostreatus) \\
\hline E1K1 & $11.84 \mathrm{a}$ \\
E1K2 & $12.66 \mathrm{a}$ \\
E1K3 & $11.72 \mathrm{a}$ \\
E2K1 & $12.49 \mathrm{a}$ \\
E2K2 & $12.02 \mathrm{a}$ \\
E2K3 & $12.77 \mathrm{a}$ \\
E3K1 & $12.15 \mathrm{a}$ \\
E3K2 & $10.96 \mathrm{a}$ \\
E3K3 & $12.78 \mathrm{a}$ \\
\hline
\end{tabular}

Tabel di atas menunjukan bahwa pemberian ekstrak kecambah jagung dan air kelapa muda tidak berpengaruh nyata terhadap berat basah jamur tiram putih. Hal ini diduga karena kurangnya konsentrasi yang diberikan. Dosis yang diberikan pada setiap perlakuan tidak bekerja efektif dalam meninngkatkan produksi. Berat basah jamur dipengaruhi juga oleh peningkatan kadar isi sel. Meningkatnya kadar isi sel akibat terakumulasinya senyawa-senyawa yang mengandung nitrogen kedalam isi sel disamping produk hasil degradasi lignin. Nutrisi yang diserap oleh miselium jamur digunakan untuk pembentukan berat tubuh buah. hal ini disebabkan karena persediaan karbohidrat, protein, kalori, fosfor, asam amino dan air di dalam media tinggi. Unsur-unsur tersebut diperlukan untuk berbagai proses metabolisme sel dalam rangka menghasilkan energi tinggi dalam bentuk ATP untuk pertumbuhan (Azizah et.al., 2019).

Banyaknya jumlah tudung yang muncul mempengaruhi hasil berat basah, hal ini diduga karena proses metabolisme dalam penyusun daging buah akan semakin meningkat sehingga kecepatan dalam pembentukan badan buah jamur menjadi lambat. Hal inilah yang menyebabkan berat basah tidak berpengaruh.
UJI EFEKTIVITAS KONSENTRASI AIR KELAPA MUDA DAN EKSTRAK KECAMBAH JAGUNG TERHADAP PERTUMBUHAN JAMUR TIRAM (Pleurotus ostreatus)
ANGGA ADRIANA IMANSYAH, MELISSA SYAMSIAH dan LIVIA PUTRI SUMIRAT 
Jumlah Rumpun Buah Jamur

Tabel 2. Rata-Rata Berat Basah Jamur Tiram (Pleurotus ostreatus).

\begin{tabular}{cc}
\hline Perlakuan & Rata-Rata Berat Basah Jamur Tiram (Pleurotus ostreatus) \\
\hline E1K1 & $1.51 \mathrm{a}$ \\
E1K2 & $1.52 \mathrm{a}$ \\
E1K3 & $1.43 \mathrm{a}$ \\
E2K1 & $1.39 \mathrm{a}$ \\
E2K2 & $1.51 \mathrm{a}$ \\
E2K3 & $1.60 \mathrm{a}$ \\
E3K1 2 & $1.58 \mathrm{a}$ \\
E3K3 & $1.67 \mathrm{a}$ \\
\hline
\end{tabular}

Hasil penelitian menunjukan bahwa tidak adanya pengaruh yang nyata terhadap parameter jumlah rumpun. Hal ini diduga karena air kelapa dan ekstrak kecambah jagung tidak mampu memenuhi kebutuhan nutrisi dan vitamin serta hormon pada jamur sehingga keduanya tidak saling berhubungan dalam mendukung memperbanyak jumlah rumpun. Vitamin berfungsi sebagai bahan tambahan atau suplemen sehingga pertumbuhan jamur menjadi lebih baik, mineral sebagai unsur hara mikro yang berguna sebagai pelengkap pada jamur. Menurut Yuliza (2019) vitamin juga berperan dalam metabolisme yang dapat mengkonversikan karbohidrat menjadi energi untuk menggerakkan aktifitas

\section{Jumlah Tudung Buah Jamur Tiram}

didalam tubuh jamur, dan dapat meningkatkan daya tahan tubuh tanaman terhadap serangan patogen. Karbohidrat sebagai sumber energi yang berfungsi untuk pertumbuhan miselium sampai terbentuknya primordia dan mendukung nutrisi untuk pertumbuhan tubuh buah jamur sampai mencapai pertumbuhan maksimal. Sejalan dengan hasil penelitian Widiastuti dan Panji (2008) bahwa pertumbuhan miselium sangat mempengaruhi proses jumlah rumpun buah, rumpun buah yang tumbuh akan semakin banyak apabila semakin banyak pula nutrisi yang diserap. Walaupun dalam baglog sudah terdapat media serbuk kayu yang mengandung selulosa sebagai nutrisnya.

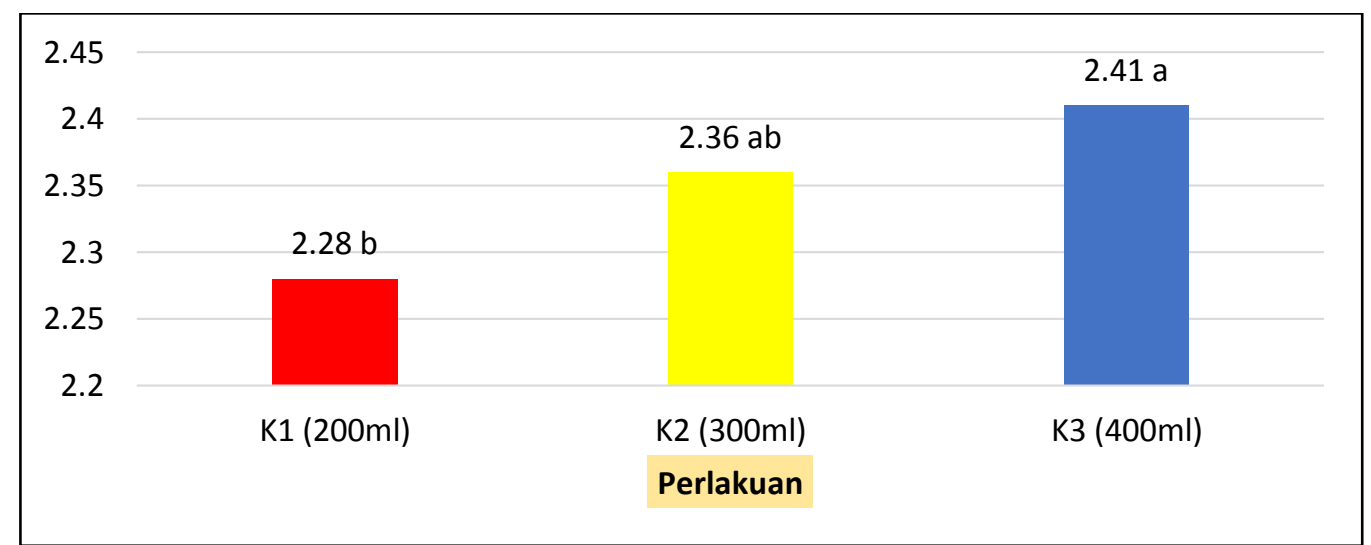

Gambar 1. Grafik rata rata jumlah tudung.

Dari grafik dapat disimpulkan bahwa perlakuan paling baik ada pada pemberian perlakuan K3 dengan nilai rata-rata jumlah tudung buah 2.41a. Hal ini diduga karena pada proses pembentukan tudung buah jamur tiram di pengaruhi berbagai macam nutrisi seperti gula, nitrogen, kalsium, kalium, vitamin, 
dan Karbohidrat (Ikhsan \& Ariani, 2017). Air kelapa muda sendiri memiliki kandungan karbohidrat yang dapat mempengaruhi jumlah tudung. Karbohidrat dalam air kelapa menjadi salah satu energi bagi pertumbuhan miselium sampai terbentuknya tubuh buah dan mendukung nutrisi untuk pertumbuhan tubuh buah sampai tubuh buah jamur mencapai pertumbuhan maksimal. Air kelapa juga mempunyai hormon sitokinin yang membantu pembelahan sel. Suriawiria (2006) menyatakan bahwa pertumbuhan jamur tiram putih dalam substrat sangat tergantung pada kandungan air.

Tinggi Buah Jamur Tiram (Pleurotus ostreatus)

Tabel 3. Rata-rata berat basah jamur tiram (Pleurotus ostreatus)

\begin{tabular}{cc}
\hline Perlakuan & Rata-Rata Berat Basah Jamur Tiram (Pleurotus ostreatus) \\
\hline E1K1 & $3.04 \mathrm{a}$ \\
E1K2 & $3.17 \mathrm{a}$ \\
E1K3 & $3.05 \mathrm{a}$ \\
E2K1 & $3.01 \mathrm{a}$ \\
E2K2 & $3.02 \mathrm{a}$ \\
E2K3 & $3.22 \mathrm{a}$ \\
E3K1 & $2.91 \mathrm{a}$ \\
E3K2 & $3.11 \mathrm{a}$ \\
E3K3 & $3.12 \mathrm{a}$ \\
\hline
\end{tabular}

Berdasarkan kesimpulan di atas pemberian air kelapa muda dan ekstrak kecambah jagung tidak berpengaruh nyata pada parameter tinggi buah jamur, hal ini diduga karena jamur tidak mampu menyerap zat organik dari media melalui hifa dan miseliumnya untuk memperoleh makanan, unsur nitrogen yang di butuhkan juga tidak mencukupi kebutuhan dalam pembentukan jamur tiram (Ikhsan \& Ariani, 2017). Nitrogen yang terkandung dalam air kelapa muda membantu merangsang pertumbuhan buah jamur. Nitrogen juga berfungsi sebagai pembentuk miselium, pembentukan protein, dan membangun enzim-enzim yang dibutuhkan untuk memecah selulosa dan lignin (Soenanto, 2000). Unsur (N) Nitrogen juga berfungsi untuk menyusun asam amino (Protein), asam nukleat, dan Nukleotida yang dengan adanya unsur nitrogen ini dapat mempercepat pertumbuhan tinggi tanaman (Azizah et.al., 2019). Maka dari itu kurang lebihnya unsur $\mathrm{N}$ dapat berpengaruh terhadap tinggi buah jamur tiram.

\section{KESIMPULAN}

Efektivitas pemberian air kelapa muda terhadap 5 parameter dalam penelitian ini menghasilkan satu parameter yang terbukti berhasil atau menunjukan pengaruh yang nyata. Parameter yang berhasil tersebut adalah jumlah tudung buah pada jamur tiram putih dengan dosis $400 \mathrm{ml}$ berkode K3. Sementara pemberian ekstrak kecambah jagung dalam tiga dosis tidak menunjukan hasil yang signifikan terhadap kelima parameter. Untuk interaksi antara pemberian air kelapa muda dan ekstrak kecambah jagung, terdapat satu parameter yang signifikan yaitu interaksi dengan kode E3K3 (Ekstrak Kecambah Jagung $400 \mathrm{ml}$ dan Air Kelapa Muda $400 \mathrm{ml}$ ) terhadap pertumbuhan miselium.

\section{DAFTAR PUSTAKA}

Aditya, R., \& Saraswati, D. 2011. 10 Jurus Sukses Beragribisnis Jamur (Rahmansyah \& S. Nugroho, Eds.). Retrieved from http://www.penebar-swadaya.com

Area, U. M. 2018. Kombinasi zat pengatur tumbuh dan komposisi media tanam terbadap pertumbuban dan produksi 
jamur tiram putih. Jakarta. Penebar Swadaya

Armawi. 2009. Pengaruh Tingkat Kemasakan Buah Kelapa Dan Konsentrasi Air Kelapa Pada Media Tanam Terhadap Pertumbuhan Jamur Tiram Putih. Skripsi. Universitas Islam Negeri Maulana Malik Ibrahim. Malang.

Azizah, N., Nurhayati, \& Hayati, R. 2019. Pengaruh Konsentrasi dan Interval Penyiraman Air Kelapa terhadap Pertumbuhan dan Hasil Jamur Tiram Putih (Pleurotus ostreatus). Jurnal Ilmiah Mahasiswa Pertanian,. 4(1):1-12.

Chazali, S., \& Pratiwi, P. S. 2009. Usaba Jamur Tiram Skala Rumah Tangga. Jakarta: Penebar Swadaya.

Dalimunthe, D. 2018. Pengaruh Pemberian Air Kelapa Terhadap Pertumbuhan Dan Produksi Jamur Tiram (Pleurotus ostreatus). Skripsi. Universitas Muhammadiyah. Sumatera Utara Medan

Damiska, S., Wulandari, R. S., \& Darwati, H. 2015. Penambahan Ragi Dan Ekstrak Biji Jagung Terhadap Pertumbuhan Tunas Manggis Secara In Vitro. Jurnal Hutan Lestari. 3(1):35-42. https://doi.org/10.1017/CBO978 $\underline{1107415324.004}$

Djarijah, N. M. dan A. S. D. 2001. Budidaya Jamur Tiram. Yogyakarta: Kanisius.

Fachirah, U. 2013. Peran Senyawa Bioaktif Tanaman Sebagai Zat Pengatur Tumbuh Dalam Memacu Produksi Umbi Mini Kentang (Solanum tuberosum L.) Pada Sistem Budidaya Aeroponik. Universitas Hasanuddin. Makasar.

Fiqullah, F. 2017. Pengaruh Sumber Indukan Miselium dan Berbagai Konsentrasi Air Rebusan Jagung Manis Sebagai Media Tumbuh Biakan Murni Jamur Tiram Putih (Pleurotus ostreatus). Skripsi. Universitas Islam Negeri Sunan Gunung Djati. Bandung

Ikhsan, M., \& Ariani, E. 2017. Pengaruh
Molase Terhadap Pertumbuhan dan Hasil Jamur Tiram Putih (Pleurotus ostreatus) pada Media Serbuk Kayu Mahang dan Sekam. Jom Faperta. 4 (2).

Johan, M. 2014. Kandungan Nutrisi Baglog Jamur Tiram Putih (Pleurotus Ostreatus) Sebagai Bahan Pakan Ternak Pada Masa Inkubasi Yang Berbeda. Universitas Hasanuddin. Makassar.

Mkhize, S. S., Cloete, J., Basson, A. K., \& Zharare, G. 2016. Performance of Pleurotus ostreatus mushroom grown on maize stalk residues supplemented with various levels of maize flour and wheat bran Performance of Pleurotus ostreatus mushroom grown on maize stalk residues supplemented with various levels of maize fl. (January 2017). https://doi.org/10.1590/1678457x.08516

Mufarrihah, L. 2009. Pengaruh Penambahan Bekatul dan Ampas Tabu Pada Media Terhadap Pertumbuhan dan Produksi Jamur Tiram Putih (Pleurotus ostreatus). Universitas Islam Negeri (UIN) Malang.

Nurhafni. 2013. Respon Pertumbuban Meristem Kentang (Solanum tuberosum. $L$ Terbadap Penambahan NAA dan Ekstrak Jagung Muda Pada Medium MS. 15.

Pagalla, D. B., \& Latunra, A. I. 2015. Respon Pertumbuban Propagul Pisang Ambon Hijau Musa acuminata Colla Pada Beberapa Konsentrasi Ekstrak Kecambah Jagung Muda Secara In Vitro. 4.

Parjimo dan Andoko. 2007. Budidaya Jamur. Jakarta: Agromedia Pustaka.

Rahayu, S., \& Setyo, D. 2015. Uji Perkembangbiakan Miselia Bibit Jamur Tiram Putih (Pleorutus ostreatus) Dengan Subtrat Campuran Air Kelapa Dan Air Leri. Agri-Tek. 16 (2).

Rajiman, R. 2018. Pengaruh Zat Pengatur Tumbuh (ZPT) Alami Terhadap Hasil Dan Kualitas Bawang Merah. Prosiding Seminar Nasional Fakultas Pertanian UNS. 2(1):A--327. 
Retrieved

from .http://jurnal.fp.uns.ac.id/index.ph p/semnas/article/view/1068/839

Salisbury, F. B., \& Ross, C. 1992. Fisiologi Tumbuhan. Bandung: Institut Teknologi Bandung.

Soenanto, H. 2000. Jamur Tiram Budidaya dan Peluang Usaha. Semarang: Penerbit Aneka Ilmu.

Stevanie, S. 2011. Pengaruh Penambahan Molase Dalam Berbagai Media Pada Jamur Tiram Putih (Pleurotus ostreatus). Skripsi. Universitas Sebelas Maret. Surakarta.

Suhaeni, Yunus, N. M., Nurjannah, S., \& Sari, A. 2018. Pertumbuhan dan Produktivitas Jamur Tiram Putih (Pleurotus ostreatus) pada Media Tanam Sabut Kelapa Sawit (Elaeis guinensis) dan Kulit Durian (Durio zibethinus). Prosiding Seminar Nasional Megabiodiversitas Indonesia. (April), 26-30.

Suriawiria. 2006. Budidaya Jamur Tiram. Yogyakarta: Kanisius.

Umniyatie, S., Astuti, Pramiadi, D., \& Henuhili, V. 2015. Budidaya Jamur Tiram (Pleuretus sp.) Sebagai Alternatif Usaha Bagi Masyarakat Korban Erupsi Merapi Di Dusun
Pandan, Wukisari, Cangkringan, Sleman DIY. Inotek. 17(2):162-175.

Widiastuti, H., \& Panji, T. 2008). Produksi dan Kualitas Jamur Tiram (Pleurotus ostreatus) Pada Beberapa Konsentrasi Limbah Sludge Pabrik Kertas. Menara Perkebunan. 76 (2):104-116.

Yong, J. W. H., Ge, L., Ng, Y. F., \& Tan, S. N. 2009. The chemical composition and biological properties of coconut (Cocos Nucifera L.) water. Molecules. 14(12):5144-5164. https://doi.org/10.3390/molecules 14125144

Yuliza, M. 2019. Pengaruh Pemberian Aair Kelapa Dan Air Leri Terhadap Pertumbuhan Dan Hasil Jamur Tiram Putih (Pleurotus ostreatus). Jurnal Ilmiah Sain Teknologi, Ekonomi, Sosial dan Budaya. 3(1):24-28.

Zubaidah, S. 2013. Peningkatan Pertumbuhan dan Hasil Jamur Tiram (Pleurotus ostreatus) Melalui Variasi Komposisi Media Tanam. Jurnal Agripeat. 14(2):96.

Zulkarnain. 2009. Kultur Jaringan Tanaman Solusi Perbanyakan Tanaman Budidaya. Jakarta: Bumi Aksara.
UJI EFEKTIVITAS KONSENTRASI AIR KELAPA MUDA DAN EKSTRAK KECAMBAH JAGUNG TERHADAP PERTUMBUHAN JAMUR TIRAM (Pleurotus ostreatus)
ANGGA ADRIANA IMANSYAH, MELISSA SYAMSIAH dan LIVIA PUTRI SUMIRAT 